\title{
Ground Water Quality Assessment in the Kazaure Environs for Drinking Purpose using the Water Quality Index Tool
}

\author{
Terlumun Adagba $^{\# 1}$, Aliyu Ibrahim Kankara ${ }^{* 2}$, Musa Idris Ado ${ }^{* 3}$ \\ ${ }^{1}$ Lecturer II, Dept. of Civil Engineering, Faculty of Engineering, Federal University Dutsin-Ma, Katsina, Nigeria. \\ ${ }^{2}$ Senior Lecturer, Department of Geology, Federal University Dutsin-Ma, Katsina, Nigeria. \\ ${ }^{3}$ Department of Geology, Rabiu Musa Kwankwaso College of Advanced and Remedial Studies, Tudun Wada, Kano, Nigeria. \\ Corresponding Author Email id:tadagba@fudutsinma.edu.ng. ORCID: https://orcid.org/0000-0002-0461-7185
}

\begin{abstract}
This study presents the findings of an assessment of the ground water quality for drinking purposes using Water Quality Index (WQI). To ascertain the water quality, detailed physical and chemical analysis of water samples was carried out on samples. Samples from twelve (12) sampling points were taken and analysis was carried out on several parameters such as $\mathrm{pH}$, Temperature, Electrical Conductivity (EC), total dissolved solids (TDS), Sodium, Potassium, Calcium, Fluoride, Chloride, Bicarbonates, Nitrate, Sulphate, Magnesium, Iron. Analysed parameters were compared with the World Health Organisation (WHO). It was observed that most of the water sample parameters conformed to the standards for Drinking water. The Water Quality Index values obtained ranged from 36.32 to 113.11, signifying a water quality class ranging from excellent to poor water quality. From the classification of the samples, five (5) samples indicating about $41.67 \%$ of the total water sample was classed as having "excellent" water quality (WQI < 50), Six (6) samples representing about $50.00 \%$ of the total water sample showed "good" water quality (WQI 50-100) and one (1) which is 8.33\% as having "poor" water quality (WQI>100). The low values of WQI in the water samples indicate that water obtained from this area is suitable for drinking with little or no treatment.
\end{abstract}

Keywords - Water Quality Index; Groundwater; Unit Weight; Physio-Chemical Parameters; Drinking Water.

\section{Introduction}

Water is a natural resource on which human life and existence depends majorly upon. According to Gupta et al. (2017), water remains the main requirement for Human and Industrial growth. The obtainability of good quality water is a crucial factor for preventing disease and improving life quality (Hamaidi-Chergui et al., 2013). Between 5 million10 million people, mostly children die from water-related diseases worldwide yearly. Consumption of water containing bacteria, viruses, or parasites causes approximately 250 million cases of water-related diseases each year, hence, making water quality control and its availability of great importance in many parts of the World. WHO (2011).

According to Selvakumar et al. (2014) groundwater quality depends on the composition of recharge water, its interaction with the soil, the soil-gas interaction, the rock which it interfaces with in the unsaturated zone, its residence time, and the reactions within the aquifer. It is also defined by both natural processes (dissolution and precipitation of minerals, groundwater velocity, quality of recharge water, and interaction with other types of water aquifer) and anthropogenic activities (Andrade et al., 2008). As competition for resources intensifies, the need for water resources information based on sustained, robust monitoring networks for tracking the quantity and quality of streamflow and ground water has never been greater
(Hirsch, 2011). Aquifers in geological terms refers to bodies of saturated rocks or geological formations through which volumes of water find their way into wells and springs. Aquifers are classed into (1) confined and (2) unconfined aquifers based on water table location within the subsurface, its structure and hydraulic conductivity. They generally serve as water storing bodies and could dry up due to over abstraction. An example is the groundwater depletion in the upper aquifer of the Chad formation in the chad basin of the North Eastern Nigeria (Adamu et al.2020).

The regional aquifers in many areas of northern Nigeria are commonly associated with sedimentary strata, extending through entire zones (Kankara \& Muktar, 2018). These aquifers do not need any reconnaissance and full survey before they can be dug to obtain water. According to Kankara and Idris (2020) any borehole drilled within this area is expected to have high yield than in the other geological zones/formations. Groundwater occurrence is limited to the weathered part of the basement and fractured zones. Different portions exhibit different permeability and porosity and can therefore be said to be heterogeneous. Thus, crystalline rocks are multiple aquifer system instead of a single homogenous aquifer (Ogunjobi, 1983).

\subsection{The Study Area}

The study area is located in northwestern part of Kano State, also covering some parts of Jigawa and Katsina States. It is part of Kazaure schist belt, north-western 
Nigeria, and lies between latitude $12^{\circ} 30^{\prime} 00^{\prime \prime} \mathrm{N}$ to $12^{\circ} 45^{\prime}$ $00^{\prime \prime} \mathrm{N}$, and longitude $8^{\circ} 15^{\prime} 00^{\prime \prime} \mathrm{E}$ to $8^{\circ} 30^{\prime} 00^{\prime \prime} \mathrm{E}$, covering an area of about $770.063 \mathrm{~km}^{2}$ (Figure 1). It is accessible through major roads, like Kano-Danbatta-Kazaure-Daura road, Kazaure-Roni-Ingawa and Kazaure- Shuwaki-Lamba road. There are also numerous networks of footpath throughout the area (Kankara \& Idris, 2020).

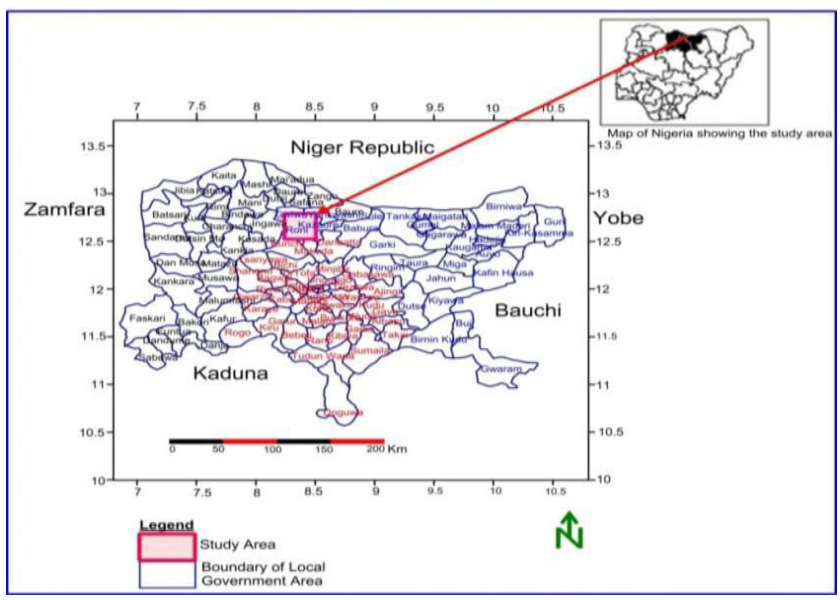

Fig. 1: Location map of the Study Area

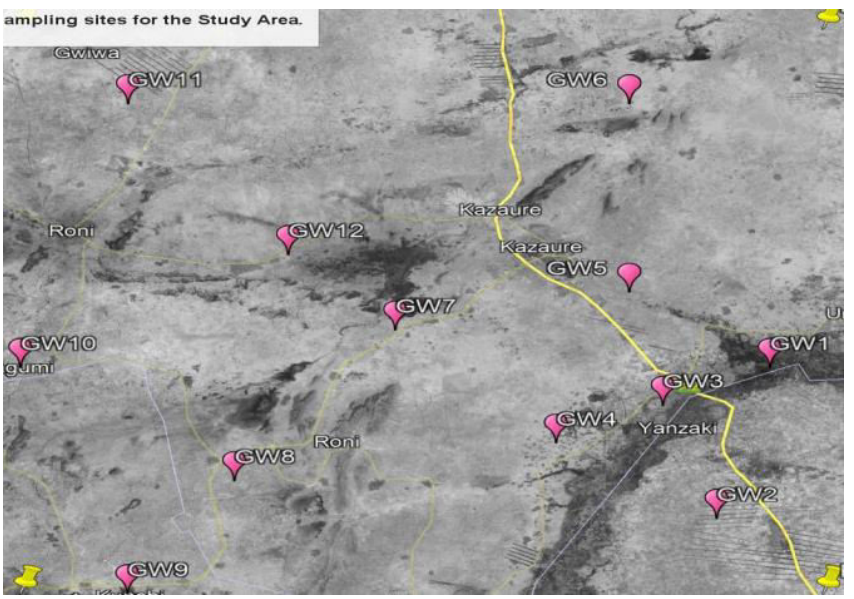

Fig. 2: Sampling locations for the Study Area

\subsection{Relief and Drainage}

The landforms in the area generally conform to those obtainable in many parts of northern Nigeria. It is characterized by flat to undulating relief. The geology of the area controls and influences the pattern of the drainage. Highly weathered minerals such as muscovite, biotite and feldspar of the metasediments of the area, result to the formation of secondary clay minerals (kaolinite). Alteration of these minerals favoured a relatively high storage capacity but low permeability of groundwater (Acworth, 1987). Low permeability produced fine drainage texture which indicates a high frequency of streams and its tributaries in a dendritic pattern (tree branches form), especially near metasediment ridges of Kazaure area. The area experiences an average annual rainfall of about $700 \mathrm{~mm}$.

Major rivers in the area include, Tuwari, Gari, Kiye, Sabke and Tagwai. The Tuwari River flow north-eastwards through a rocky terrain and turn south-eastern near Kazaure town. River Gari flows north-eastwards across regional strike to its intersection with the Tagwai River, from there it more easterly flow direction similar to that River Kiye. However, River Kiye is an important river and empties into lake Kiye. The other lakes are Dandi, Dakwat, Kwaita and Wawan-Rafi.

\subsection{Geological/Hydrogeological Mapping}

According to Kankara and Idris (2020) the Chad Formation is of lacustrine origin, and was deposited by rivers flowing towards Lake Chad on the Basement Complex during the Plio-Pleistocene. Aquifers in this area fall within the regional and localised aquifers. In the regional aquifers, the basement complex or water-bearing objects here are regional aquifers and do not exceed 90 meters. (Kankara et al., 2021). According to Kankara and Idris (2020), depths of boreholes drilled into the migmatitegniess in around regional aquifers fall within the range of $25.0 \mathrm{~m}$ to $79.50 \mathrm{~m}$ for boreholes tapping the Biotite granite rocks. Regional aquifers in the southern parts of the study area are extended or elongated, have a high yield and cover many kilometers. The localized aquifers on the other hand have very low to moderate yield. The average yield of an aquifer here is 0.2 to 0.5 liter per second. If the aquifer is soft overbudden with very good hydrologic characteristics, the yield can stand at $0.2 \mathrm{1} / \mathrm{s}$ or more.

A few studies have been carried out in the study area. (Musa et al., 2019) conducted a hydrogeochemistry of the groundwater from this area using multivariate statistics. The study aimed at determining the groundwater geochemistry and the factors controlling the water chemistry. He reported that the physiochemical evaluation of groundwater showed evidence of local contamination and concluded that the water-rock interaction, tectonics and anthropogenic factors affected the studied groundwater. (Kankara \& Idris, 2020), carried out a Mapping of the geology and structural features of the Kazaure area with a look at establishing a groundwater potential model for the area. Groundwater potential modeling of the area revealed three zones of groundwater potential. These include zones of low, medium and high potentials.

The uniqueness of this study however is based in the fact that water quality from the study area have not been determined using the Water Quality Index. This research therefore takes a look at the suitability of the ground water 
in the Kazaure area for drinking purposes using the Water Quality Index (WQI).

\section{Materials and Methods}

\subsection{Physio-Chemical Analysis}

Water samples were obtained from twelve (12) sampling points. Parameters analysed include $\mathrm{pH}$, Electrical Conductivity (EC), Total Dissolved Solids (TDS), Temperature, Calcium, Magnesium, Potassium, Sodium, Iron, Sulphate, Bicarbonates, Chlorine, Nitrate and Fluoride. Electrical conductivity meter was used to determine the electrical conductivity. The drying process was employed in the determination of total dissolved solids. Determination of $\mathrm{pH}$ Value was done using the $\mathrm{pH}$ meter. The Atomic Absorption Spectrophotometer (AAS) was used to determine the concentration of calcium, magnesium, potassium, sodium and iron while digital titration was used to determine the concentration of sulphate, bicarbonate, chlorine and nitrates.

\subsection{Water Quality Index}

Water Quality Index is a mathematical equation that provides a clear understanding of the quality of surface and groundwater (Chaudhry \& Sachdeva, 2020). It is a means of integrating a wide range of information into a simpler form and as such is considered as the most effective tool in water quality assessment (Akter et al., 2016). According to Olusola. (2020) water quality index helps in better management of water quality issues and improves the effectiveness of protective measures. It is a simplified and precise means employed to verify the deficiency in the quality of water. WQI helps to evaluate the effect of each water parameter on the overall water quality by assigning weights to each water quality parameter and summarizing them into a single figure, thus giving an indication of the classification of water in terms of its quality. Several researchers have used this tool and reported on its viability in water quality assessment. Alobaidy et al. (2010); Saeedi et al. (2010); Gebrehiwot et al. (2011); Kumar and James. (2012); Tyagi et al. (2013); Batabyal and Chakraborty (2015); Akinbile and Omoniyi (2018); Kawo and Karuppannan (2018); Agrama. (2019); Ameur et al. (2019); Khan et al. (2020); Iwar et al. (2021). Recently, researchers have reported on the application of the GIS-GWQI (Adimalla and Taloor (2020)) and the Hybrid fuzzy GIS based WQI in assessing water quality (Hosseini-Moghari et al. (2015); Gorai et al. (2016); Jha et al. (2020))

\subsection{Water Quality Index Computation}

Computation of the Water Quality Index involves these successive steps (Ramakrishnaiah et al., 2009); (Rokbani et al., 2011); (Aly et al., 2014); (Fathi et al., 2015).

Step 1: Assigning of weights. Weights were assigned to the parameters according to their importance in the overall water quality, with a maximum value of five (5) and the minimum of one (1). A higher weight was assigned to the most significant parameters, and lesser weights attached to the less significant parameters (Table 2).

Step 2: Relative weight computation. Relative weight $\left(W_{i}\right)$ was obtained using the formula:

$$
W i=\frac{w i}{\sum_{i=1}^{n} w i}
$$

Where,

$W_{i}$ is the relative weight, $w_{i}$ is the weight of each parameter and $n$ is the number of parameters (Table 1).

Step 3: Quality rating scale (qi) computation. qi was obtained for each parameter using the equation;

$$
q i=\left(\frac{C i}{s i}\right) \times 100
$$

Where,

$q_{i}$ is the quality rating, $C_{i}$ is the concentration of each chemical parameter in each water sample $(\mathrm{mg} / \mathrm{L}), S_{i}$ is the WHO standard for each chemical parameter $(\mathrm{mg} / \mathrm{L}) \mathrm{WHO}$ (2018).

Step 4: Calculation of the Water Quality Index (WQI). $W_{i}$ and $q_{i}$ used to compute the $S L i$ for each chemical parameter. WQI was finally obtained from Equation (4) below:

$$
\begin{aligned}
& S L i=W i \leqslant q i \\
& W Q I=\sum_{i=1}^{n} S L i
\end{aligned}
$$

Where SLi is the sub-index; Wi is the relative weight. The WQI for a sample is therefore finally obtained by summing SLi for all the parameters. WQI values computed is then used to classify water into five types: "Excellent", "Good", "Poor", "Very Poor" and "Unsuitable" (Table 4).

\section{Results and Discussion}

The values obtained from the physiochemical analysis of the parameters measured and the statistical descriptive analysis are as presented in Table 1 . The values obtained were compared with the World Health Organisation (WHO) standard.

The $\mathrm{pH}$ values of samples from this area ranged from $4.90-6.08$ with a mean and standard deviation of $5.57 \pm$ 0.39 . This indicates that the samples were acidic and below the recommended levels of the World Health Organisation (WHO) of $6.5-8.5$. The range, mean and standard deviation for the other parameters presented in (table 1) shows TDS $(0.00-230$ and $100 \pm 75.00) \mathrm{mg} / \mathrm{L}$, Temperature $(28.80-33.40$ and $30.53 \pm 1.25){ }^{\circ} \mathrm{C}$, EC 
$(10.00-390.00$ and $170.83 \pm 113.10) \mu \mathrm{S} / \mathrm{cm}, \mathrm{Na}^{2+}(0.00-$ 90.00 and $35.00 \pm 23.98) \mathrm{mg} / \mathrm{L}, \mathrm{K}^{+}(5.00-165.00$ and $38.98 \pm 44.12) \mathrm{mg} / \mathrm{L}, \mathrm{Ca}^{2+}(4.00-15.00$ and $6.92 \pm 2.75)$ $\mathrm{mg} / \mathrm{L}, \mathrm{Mg}^{2+}(0.00-22.10$ and $4.30 \pm 5.50) \mathrm{mg} / \mathrm{L}, \mathrm{Fe}^{2+}(0.52$ -1.90 and $1.16 \pm 0.45) \mathrm{mg} / \mathrm{L}, \mathrm{F}^{-}(0.46-0.58$ and $0.53 \pm$ $0.04) \mathrm{mg} / \mathrm{L}, \mathrm{Cl}^{-}(28.40-85.20$ and $55.63 \pm 14.83) \mathrm{mg} / \mathrm{L}$, $\mathrm{HCO}_{3}{ }^{-}(30.50-345.00$ and $106.53 \pm 82.11) \mathrm{mg} / \mathrm{L}, \mathrm{NO}_{3}{ }^{-}$ $(10.00-18.60$ and $14.47 \pm 2.95) \mathrm{mg} / \mathrm{L}$ and $\mathrm{SO}_{4}{ }^{2-}(1.90-$ 9.52 and $4.43 \pm 2.18) \mathrm{mg} / \mathrm{L}$ respectively.

Table 1: Statistics of the Parameters analysed and Comparison with (WHO, 2018)

\begin{tabular}{|l|l|l|l|l|l|l|}
\hline Parameter & Unit & Min & Max & Mean & St.Dev & $\begin{array}{l}\text { WHO } \\
(\mathbf{2 0 1 8})\end{array}$ \\
\hline$p H$ & & 4.90 & 6.08 & 5.57 & 0.39 & $6.5-8.5$ \\
\hline$T D S$ & $m g / L$ & 0.00 & 230.00 & 100.83 & 75.00 & $500^{\mathrm{a}}$ \\
\hline Temp. & ${ }^{\circ} \mathrm{C}$ & 28.80 & 33.40 & 30.53 & 1.25 & 25 \\
\hline$E C$ & $\mu S / \mathrm{cm}$ & 10.00 & 390.00 & 170.83 & 113.10 & $1000^{\mathrm{a}}$ \\
\hline $\mathrm{Na}^{+}$ & $m g / L$ & 0.00 & 90.00 & 35.00 & 23.98 & 200 \\
\hline $\mathrm{K}^{+}$ & $m g / L$ & 5.00 & 165.00 & 38.98 & 44.12 & $12^{\mathrm{a}}$ \\
\hline $\mathrm{Ca}^{2+}$ & $m g / L$ & 4.00 & 15.00 & 6.92 & 2.75 & $75^{\mathrm{a}}$ \\
\hline $\mathrm{Mg}^{2+}$ & $m g / L$ & 0.00 & 22.10 & 4.30 & 5.50 & $50^{\mathrm{a}}$ \\
\hline $\mathrm{Fe}^{2+}$ & $m g / L$ & 0.52 & 1.90 & 1.16 & 0.45 & 0.3 \\
\hline $\mathrm{F}^{-}$ & $m g / L$ & 0.46 & 0.58 & 0.53 & 0.04 & 1.5 \\
\hline $\mathrm{Cl}^{-}$ & $m g / L$ & 28.40 & 85.20 & 55.63 & 15.83 & 250 \\
\hline $\mathrm{HCO}_{3}^{-}$ & $m g / L$ & 30.50 & 345.00 & 106.53 & 82.11 & $120^{\mathrm{a}}$ \\
\hline $\mathrm{NO}_{3}{ }^{-}$ & $m g / L$ & 10.00 & 18.60 & 14.47 & 2.95 & 50 \\
\hline $\mathrm{SO}_{4}{ }^{2-}$ & $m g / L$ & 1.90 & 9.52 & 4.43 & 2.18 & 250 \\
\hline
\end{tabular}

${ }^{a}$ WHO (2011)

Table 2 shows the parameters and the weights assigned according to the importance of each parameter in drinking water. Parameters which are considered most significant were assigned a higher weight while those considered less important in drinking water were assigned a lower value. The relative weights used in this study are also as presented.

Table 2: Assigned weights and relative weights of parameters considered

\begin{tabular}{|l|l|l|l|}
\hline $\begin{array}{l}\text { Chemical } \\
\text { Parameters }\end{array}$ & Weights $\left(\boldsymbol{w}_{\boldsymbol{i}}\right)$ & $\begin{array}{l}\text { WHO } \\
\mathbf{2 0 1 8}(\mathrm{Si})\end{array}$ & $\begin{array}{l}\text { Relative Weights } \\
\left(\boldsymbol{W}_{i}\right)\end{array}$ \\
\hline $\mathrm{pH}$ & 4 & $6.5-8.5$ & 0.08 \\
\hline $\mathrm{TDS}$ & 4 & 500 & 0.08 \\
\hline $\mathrm{EC}$ & 3 & 1000 & 0.06 \\
\hline $\mathrm{Na}^{+}$ & 5 & 200 & 0.10 \\
\hline $\mathrm{K}^{+}$ & 2 & 12 & 0.04 \\
\hline $\mathrm{Ca}^{2+}$ & 5 & 75 & 0.10 \\
\hline $\mathrm{Mg}^{2+}$ & 4 & 50 & 0.08 \\
\hline $\mathrm{Fe}^{2+}$ & 2 & 0.3 & 0.04 \\
\hline $\mathrm{F}^{-}$ & 5 & 1.5 & 0.10 \\
\hline $\mathrm{Cl}^{-}$ & 5 & 250 & 0.10 \\
\hline $\mathrm{HCO}_{3}^{-}$ & 4 & 120 & 0.08 \\
\hline $\mathrm{NO}_{3}^{-}$ & 4 & 50 & 0.08 \\
\hline $\mathrm{SO}_{4}{ }^{2-}$ & 3 & 250 & 0.06 \\
\hline $\mathrm{Total}^{2}$ & $\sum_{i=1}^{n}$ wi $=\mathbf{5 0}$ & & $\sum W i=\mathbf{1 . 0}$ \\
\hline
\end{tabular}

Table 3 presents the classification of the various water samples. The results show that GW2, GW5, GW8, GW9,
GW10 showed "excellent" water quality, GW3, GW4, GW6, GW7, GW11, GW12 exhibited "good" water quality, while GW1 has "poor" water quality. Fig 1 shows a pictorial representation of the classification and WQI values for the water samples.

Table 3: Water Quality Index values obtained

\begin{tabular}{|l|l|l|l|}
\hline $\begin{array}{l}\text { Water } \\
\text { sample ID }\end{array}$ & $\begin{array}{l}\text { Water } \\
\text { Source }\end{array}$ & $\begin{array}{l}\text { WQI } \\
\text { obtained }\end{array}$ & Class \\
\hline$G W 1$ & BH & 113.11 & Poor \\
\hline$G W 2$ & BH & 45.41 & Excellent \\
\hline$G W 3$ & BH & 51.77 & Good \\
\hline$G W 4$ & W & 69.20 & Good \\
\hline$G W 5$ & W & 39.81 & Excellent \\
\hline$G W 6$ & BH & 70.17 & Good \\
\hline$G W 7$ & W & 56.52 & Good \\
\hline$G W 8$ & BH & 46.44 & Excellent \\
\hline$G W 9$ & W & 44.57 & Excellent \\
\hline$G W 10$ & W & 36.32 & Excellent \\
\hline$G W 11$ & W & 53.73 & Good \\
\hline$G W 12$ & W & 51.75 & Good \\
\hline
\end{tabular}

BH=Bore hole, $W=$ Well

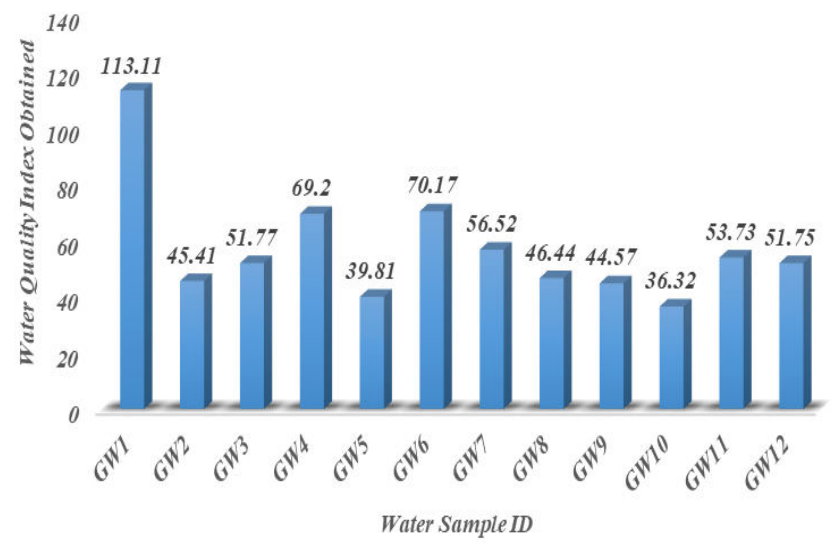

Fig.3: Water Quality Index Obtained for each Water Sample ID

Table 4: Water Quality Classification

\begin{tabular}{|l|l|l|l|}
\hline $\begin{array}{l}\text { Index } \\
\text { Values } \\
\text { obtained }\end{array}$ & $\begin{array}{l}\text { Water } \\
\text { Quality } \\
\text { Class }\end{array}$ & $\begin{array}{l}\text { No. of } \\
\text { Samples }\end{array}$ & Percentage \\
\hline$<50$ & Excellent & 5 & $41.67 \%$ \\
\hline $50-100$ & Good & 6 & $50.00 \%$ \\
\hline $100-200$ & Poor & 1 & $8.33 \%$ \\
\hline $200-300$ & Very poor & - & $0 \%$ \\
\hline$>300$ & Unsuitable & - & $0 \%$ \\
\hline
\end{tabular}




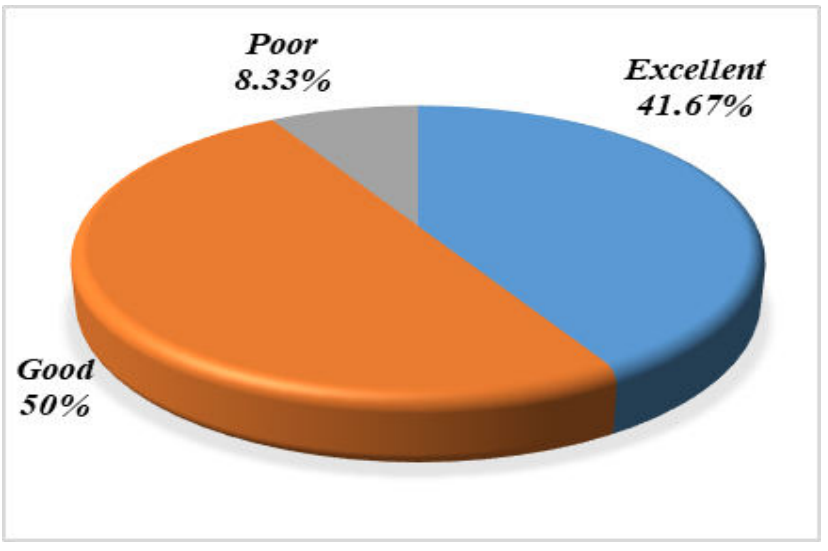

Fig. 4a: Pie chart of water quality percentage in each class

Table 4 presents the classification by percentage. The results show that five (5) sampling points representing about $41.67 \%$ have "excellent" water quality, six (6) sampling points representing 50\% have "good" water quality while one (1) sampling point representing $8.33 \%$ has "poor" water quality. Fig $2 \mathrm{a}$ and b gives a pictorial representation of the water samples classification by percentage.

The Physiochemical parameters were analysed using the Pearson Correlation Coefficient to determine the relationship between these parameters. Table 5 shows the

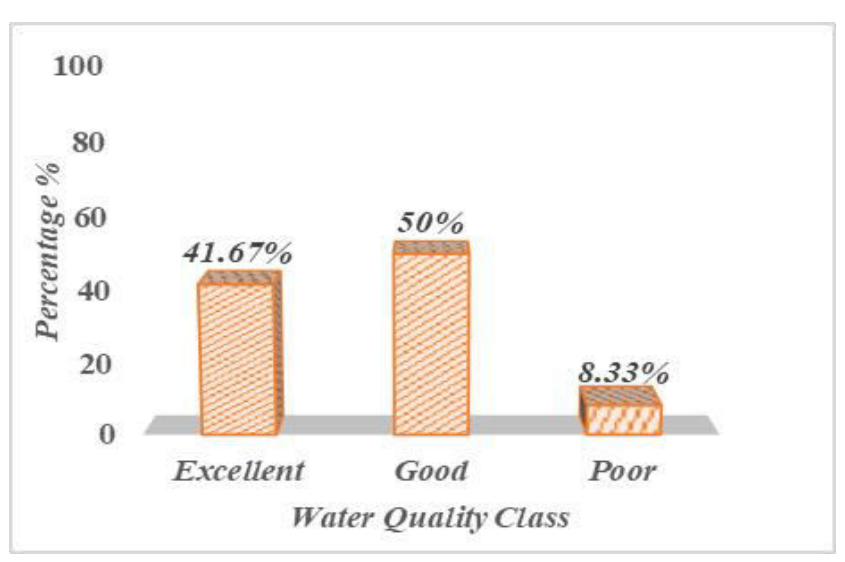

Fig. 4b: Bar chart of water quality percentage in each class

interrelationship of these groundwater parameters. A high correlation is observed between EC and TDS $(r=0.914)$. This suggests that ions which are necessary for electrical conductivity in water increases with increase in dissolved solids.

Significant positive correlation was observed between EC and TDS with $\mathrm{Na}^{+}, \mathrm{K}^{+}, \mathrm{Cl}^{-}, \mathrm{HCO}_{3}^{-}$and $\mathrm{SO}_{4}{ }^{2-}$. Significant positive correlation was also observed between some chemical parameters notably, $\mathrm{Mg}^{2+}$ and $\mathrm{Ca}^{2+}(0.929)$, $\mathrm{Cl}^{-}$and $\mathrm{K}^{+}(0.795), \mathrm{HCO}_{3}{ }^{-}$and $\mathrm{K}^{+}(0.71), \mathrm{HCO}_{3}{ }^{-}$and $\mathrm{Na}^{+}$ (0.586), $\mathrm{Fe}^{2+}$ and $\mathrm{NO}_{3}^{-}(0.578)$ and $\mathrm{Fe}^{2+}$ and $\mathrm{Ca}^{2+}(0.531)$

Table 5: Correlation Matrix for the considered parameters

\begin{tabular}{|c|c|c|c|c|c|c|c|c|c|c|c|c|c|c|}
\hline & $p H$ & TDS & $E C$ & $\mathrm{Na}^{+}$ & $K^{+}$ & $\mathrm{Ca}^{2+}$ & $\mathrm{Mg}^{2+}$ & $F e^{2+}$ & $F^{-}$ & $\mathrm{Cl}^{-}$ & $\mathrm{HCO}_{3}^{-}$ & $\mathrm{NO}_{3}^{-}$ & $\mathrm{SO}_{4}{ }^{2-}$ & $W Q I$ \\
\hline$p H$ & 1 & & & & & & & & & & & & & \\
\hline$T D S$ & 0.123 & 1 & & & & & & & & & & & & \\
\hline$E C$ & -0.014 & 0.914 & 1 & & & & & & & & & & & \\
\hline $\mathrm{Na}^{+}$ & 0.001 & 0.54 & 0.653 & 1 & & & & & & & & & & \\
\hline$K^{+}$ & -0.371 & 0.656 & 0.635 & 0.088 & 1 & & & & & & & & & \\
\hline $\mathrm{Ca}^{2+}$ & 0.329 & -0.541 & $\begin{array}{l}-0.61 \\
\end{array}$ & -0.6 & -0.341 & 1 & & & & & & & & \\
\hline$M g^{2+}$ & 0.244 & -0.42 & -0.41 & -0.443 & -0.215 & 0.929 & 1 & & & & & & & \\
\hline $\mathrm{Fe}^{2+}$ & -0.245 & -0.584 & -0.644 & -0.756 & -0.122 & 0.531 & 0.392 & 1 & & & & & & \\
\hline$F^{-}$ & 0.156 & -0.686 & -0.625 & -0.102 & -0.704 & 0.428 & 0.263 & 0.058 & 1 & & & & & \\
\hline $\mathrm{Cl}$ & -0.308 & 0.569 & 0.509 & 0.014 & 0.795 & -0.138 & -0.009 & -0.055 & -0.504 & 1 & & & & \\
\hline $\mathrm{HCO}_{3}^{-}$ & -0.169 & 0.624 & 0.739 & 0.586 & 0.71 & -0.268 & -0.048 & -0.464 & -0.442 & 0.463 & 1 & & & \\
\hline $\mathrm{NO}_{3}^{-}$ & 0.018 & -0.122 & -0.304 & -0.446 & -0.069 & 0.475 & 0.361 & 0.578 & 0.031 & 0.025 & -0.327 & 1 & & \\
\hline $\mathrm{SO}_{4}{ }^{2-}$ & 0.07 & 0.638 & 0.374 & 0.103 & 0.48 & -0.241 & -0.371 & -0.179 & -0.294 & 0.46 & 0.167 & 0.372 & 1 & \\
\hline$W Q I$ & -0.452 & 0.377 & 0.373 & -0.189 & 0.889 & -0.006 & 0.092 & 0.288 & -0.596 & 0.783 & 0.565 & 0.159 & 0.305 & 1 \\
\hline
\end{tabular}

\section{Conclusion}

The quality of life of a group of people depends largely on the quality of water they have access to. The water quality for the purpose of drinking in the Kazaure area was investigated using the water quality index (WQI). The physio-chemical parameters assessed was compared with the WHO standards and most of the parameters measured were found to be within limits. The water quality index values obtained show that the water is generally of good quality with about $91.67 \%$ having values below 100 (WQI $<100$ ). The water quality index ranged between 36.32 to 113.11. It can therefore be concluded based on the study that the water in this area is generally good for drinking with little to no treatment.

\section{References}

[1] Acworth, R. I. (1987). The Development of Crystalline Basement Aquifers in a Tropical Environment. Quarterly Journal of Engineering Geology, 20, 265-272. 
[2] Adamu, S., Sadiq, H. M., Kodomi, M. G., \& Wulo, I. B. (2020). Groundwater Depletion in the Upper Aquifer of the Chad Formation, Chad Basin, North-Eastern Nigeria. Nigerian Journal of Technology (NIJOTECH). , 39(2), 621-631. https://doi.org/10.4314/njt.v39i2.34

[3] Adimalla, N., \& Taloor, A. K. (2020). Hydrogeochemical Investigation of Groundwater Quality in the Hard rock Terrain of South India using Geographic Information System (GIS) and Groundwater Quality Index (GWQI) Techniques. Groundwater for Sustainable Development, 10:100288 https://doi.org/10.1016/ j.gsd.2019.100288

[4] Agrama., A. (2019). Spatial Distribution Mapping for Groundwater Quality Index, East and West Delta, Egypt. AIP Conference Proceedings 2123, 030017. https://doi.org/10.1063/1.5117048.

[5] Akinbile, C. O., \& Omoniyi, O. (2018). Quality Assessment and Classification of Ogbese River using Water Quality Index (WQI) Tool. . Sustainable Water Resources Management. https://doi.org /10.1007/s40899-018-0226-8

[6] Akter, T., Jhohura, F. T., Akter, F., Chowdhury, T. R., Mistry, S. K., Dey, D., \& Rahman, M. (2016). Water Quality Index for measuring Drinking Water Quality in Rural Bangladesh: A Cross Sectional Study. Journal of Health, Population and Nutrition., 35(1), 4.

[7] Alobaidy, A. H. M. J., Abid, H. S., \& Mauloud, B. K. (2010). Application of water quality index for assessment of Dokan Lake ecosystem, Kurdistan region, Iraq. . Water resources and Protection, 2, 792-798.

[8] Aly, A. A., Al-Omran, A. M., \& Alharby, M. M. (2014). The Water Quality Index and Hydrochemical Characterisation of Groundwater Resources in Hafar Albatin, Saudi Arabia. Arab J. Geosci. https://doi.org/10.1007/s12517-014-1463-2

[9] Ameur, M., Hamzaoui-Azaza, F., \& Gueddari., M. (2019). Water quality assessment of the Triassic aquifer, SE Tunisia, for drinking water supply. E3S Web of Conferences 98, 09002,

[10] Andrade, E., Palacio, H. A. Q., Souza, I. H., Leao, R. A., \& Guerreio, M. J. (2008). Land Use Effects in Groundwater Composition of an Alluvial Aquifer by Multivariate Techniques. Environmental Research, 106, 170-177. https://doi.org/10.1016/j.envres.2007.10.008

[11] Batabyal, A. K., \& Chakraborty, S. (2015). Hydrogeochemistry and water quality index in the Assessment of Groundwater quality for drinking uses. Water Environ. Res., 87, 607.

[12] Chaudhry, A. K., \& Sachdeva, P. (2020). Groundwater quality and Non-Carcinogenic health risk assessment of Nitrate in the semi-arid region of Punjab, India. Journal of Water and Health, 18(6), 10731083. https://doi.org/10.2166/wh.2020.121

[13] Fathi, P., Ebrahimi, E., Mirghafarry, M., \& Ofogh., A. E. (2015). Water quality assessment in Choghakhor wetland using water quality index (WQI). Iranian Journal of Fisheries Sciences. , 15(1), 508523.

[14] Gebrehiwot, A. B., Tadessse, N., \& Jigar., E. (2011). Application of water quality index to assess suitablity of groundwater quality for drinking purposes in Hantebet watershed, Tigray, Northern Ethiopia. ISABB Journal of Food and Agriculture Science 1(1), 22-30.

[15] Gorai, A. K., Hasni, S. A., \& Iqtal, J. (2016). Prediction of Ground water quality index to assess suitability of Drinking Purposes using Fuzzy rule-based approach. Applied Water Science, 6(4), 393-405.

[16] Gupta, N., Pandey, P., \& Hussain., J. (2017). Effect of physicochemical and biological parameters on the quality of river water of Narmada, Madhya Pradesh, India. Water Sci... https://doi.org/10.1016/j.wsj.2017.03.002

[17] Hamaidi-Chergui, F., Benouaklil, M. B. E. F., \& Hamaidi., M. S (2013). Preliminary Study on Physico-Chemical Parameters and Phytoplankton of Chiffa River (Blida, Algeria). Journal of Ecosystems, 9 pages, Article Article ID148793. https://doi.org/10.1155/2013/148793

[18] Hirsch, R. M. (2011). A Perspective in non-stationary and water management. Journal of the American Water Resources Association, 47(3), 436-446.

[19] Hosseini-Moghari, S. M., Ebraimi, K., \& Azarnivand, A. (2015). Groundwater Quality Assessment with respect to Fuzzy Water
Quality Index (FWQI): An Application of expert systems in Environmental Monitoring. Earth Sciences. , 74(10), 7229-7238.

[20] Iwar, R. T., Utsev, J. T., \& Hassan, M. (2021). Assessment of heavy metal and physico-chemical pollution loadings of River Benue water at Makurdi using Water Quality Index (WQI) and Multivariate Statistics. Applied Water Science 11, 124. https://doi.org/10.1007/s13201-021-01456-8

[21] Jha, M. K., Shektar, A., \& Jenifer, M. A. (2020). Assessing Groundwater Quality for Drinking water supply using fuzzy-GIS based water quality Index. . Water Research. https://doi.org/10.1016/j.watres.2020.115867

[22] Kankara, I. A., \& Idris, M. A. (2020). Mapping Geology and Structural Features of Kazaure SE, NW Nigeria: Justifying Groundwater Potential Model. Researchers Review DGTH, 49(1), 121. https://doi.org/10.5937/ZbDght2001001K

[23] Kankara, I. A., Idris, M. A., \& Adagba., T. (2021). Studies in Multiple Aquifer Systems and their Comparism in the Geological Character of Kazaure Crystalline Rocks, Northwestern Nigeria. International Journal of Advances in Engineering and Management (IJAEM), 3(7), 722-734. https://doi.org/10.35629/5252-0307722734.

[24] Kankara, I. A., \& Muktar, K. (2018). Hydrogeological Analysis of Lithographic Units of Northern Katsina State, Nigeria. . FUDMA Journal of Sciences. , 2(4), 231-236.

[25] Kawo, N. S., \& Karuppannan, S. (2018). Groundwater Quality Assessment using Water Quality Index and GIS technique in Modjo River Basin, Central Ethiopia. Journal of African Earth Sciences. , 147, 300-311. https://doi.org/10.1016/j.jafrearsci.2018.06.034

[26] Khan, A., Khan, A., Naz, B., \& Rukhsar. (2020). Comparative Study of Conventional groundwater quality results with WQI Technique: A case study of Surjani Town, Karachi, Pakistan. [Research]. Sustainable Development Research, 2(2), 10-17. https://doi.org/10.30560/sdr.v2n2p10

[27] Kumar, P. J. S., \& James., E. J. (2012). Development of Water Quality Index (WQI) model for the groundwater in Tirupur District, South India. . Chin. J. Geochem. , 32, 261-268

[28] Musa, A., Adeyeye, O., Xiao, C., \& Liang, X. (2019). Hydrogeochemistry of Groundwater from Kazaure area, NW Nigeria using Multivariate Statistics. E3S Web of Conferences 98, 07001.WRI-16., https://doi.org/10.1051/e3sconf/20199807001

[29] Ogunjobi, M. B. (1983). The geochemistry of groundwater in part of River Galma Basin. National water resources institute Bulleting, 3, 11-20.

[30] Olusola., F. O. (2020). Groundwater Quality Evaluation for Drinking, Domestic and Irrigation Uses in Parts of Ode Irele Local Government Area of Ondo State, Nigeria. Water Conservation and Management, 4(1), 32-41.

[31] Ramakrishnaiah, C. R., Sadashivaiah, C., \& Ranganna, G. (2009). Assessment of water quality index for the Ground water in Tumkur, Taluk. E-Journal of Chemistry., 6(2), 523-530.

[32] Rokbani, M. K., Guoddari, M., \& Bouhlila, R. (2011). Use of Geographical Information System and Water Quality in El Khairat Deep Aquifer (Enfidha, Tunisia Sahel). Iranica Journal of Energy and Environment 2(2), 133-144.

[33] Saeedi, M., Abessi, O., Sharifi, F., \& Meraji, H. (2010). Development of groundwater quality index. . Environ. Monit. Assess. , 163, 327-335. https://doi.org/10.1007/s10661-009-0837-5

[34] Selvakumar, S., Ramkumar, K., Chandrasekar, N., Magesh, N. S., \& Kaliraj, S. (2014). Groundwater Quality and Its Suitability for Drinking and Irrigational Use in the Southern Tiruchirappalli District, Tamil Nadu, India. Applied Water Science, 1-10.

[35] Tyagi, S., Sharma, B., Singh, P., \& Dobhal, R. (2013). Water quality assessment in terms of water quality index. . Am. J. Water Resources. , 1(3), 34-38. https://doi.org/10.12691/ajwr-1-3-3

[36] Guidelines for Drinking Water Quality. World Health Organisation (WHO). WHO Press, Geneva, Switzerland. 4th edition, (2011).

[37] A Global Overview of National Regulations and Standards for Geneva: Licence: CC BY-NC-SA 3.0 IGO. ISBN 978-92-4-151376$0,(2018)$. 